COMMENT

DOI: $10.1057 /$ s41599-018-0174-9

\title{
Gender, work, non-work and the invisible migrant: au pairs in contemporary Britain
}

Rosie Cox (1) ${ }^{1}$

\begin{abstract}
Campaigns by Uber drivers, Deliveroo riders and McDonalds workers have highlighted problems with the new world of platform economies and zero-hour contracts. At the same time, the Brexit process has opened up debates about the UK's dependence on low-waged workers from the EU. Together these trends raise questions about who is going to do low-paid, labour intensive work in the future and what their rights will be. Within these debates, au pairs have been largely invisible despite the fact that they are EU workers who are depended upon by perhaps 100,000 families in the UK, and the fact that their status excludes them from protections available to other workers. This paper explores the current UK situation to examine how this invisibility is related to the gendering of the work au pairs do. While traditionally masculine jobs, such as construction work, have tended to be reimagined as self-employment, au pairing is an example of the way that traditionally feminine tasks are produced by policy discourses as 'help'. Despite this invisibility au pairs do large amounts of work, on average working $37.8 \mathrm{~h}$ per week for 'pocket money' at about half the level of the National Minimum Wage and they are increasingly taking on tasks, such as the care for very young children, that would have been done by qualified nannies in the past. In addition to the current debates over the rights of workers in new 'platform' economies, and the possible problems arising from Brexit, we need a broader conversation about work, what it is and how gendered assumptions inform government policy and curtail the rights of workers.
\end{abstract}

\footnotetext{
${ }^{1}$ Department of Geography, Birkbeck, University of London, London, UK. Correspondence and requests for materials should be addressed to R.C. (email: r.cox@bbk.ac.uk)
} 


\section{Introduction}

or many families, hosting an au pair can be an attractive solution to the increasing problems of work-life balance. Long and irregular working hours, expensive and inflexible group care, can make au pairs the most affordable, option available and, as well as looking after the kids, an au pair will clean the house, do the ironing and maybe cook dinner too. The UK is a particularly popular destination for au pairs yet despite their importance and incipient concerns about how Brexit is affecting the supply of au pairs, they remain a group who are largely ignored by policy makers and excluded from a range of legal protections. An examination of the (non)regulation of au pairing in the UK demonstrates how the gendering of particular types of work (in this case childcare and housework) plays into the production of precarious, poorly paid, 'non-work' roles. While traditionally masculine jobs, such as construction work, have been particularly prone to being reimagined as (bogus) selfemployment, au pairing is an excellent illustration of the way that traditionally feminine tasks are produced by policy discourses as 'help', rather than as work at all. The outcome of this is that au pairs have been ignored in policy debates about precarious workers and those about EU migrants despite their long working hours and increasing significance as providers of childcare; the invisibility of their work has made them invisible within public discourse.

So, what is an 'au pair'? The precise rules and details of au pairing vary by country but all national schemes have in common the idea of a young person living with a host family, carrying out household tasks in exchange for room and board and being treated 'as an equal' (the translation of 'au pair'). Some national au pair schemes are highly regulated, and the USA is a good example of this approach. In the USA all au pairs are placed by registered agencies, their visas are time limited and they must be engaged in formal education of some kind (see Chuang, 2013 for details and also a discussion of limitations and abuses of the US scheme). There are a number of countries which have partially regulated au pair sectors. For example, in countries which are members of the European Economic Area, which enables free movement of labour between member states, au pairs from outside the EEA will tend to be on visas which impose certain conditions and may offer some protections, whilst au pairs who are EEA nationals are not covered by these rules (Anving and Eldén, 2016, Calleman 2010). Then there are countries which seem to acknowledge the existence of au pairs whilst having no regulation of this category at all. The lack of formal recognition of au pairs in Australia has been exposed recently by the scandal of Peter Dutton, ultra-hawkish immigration minister, intervening to grant a tourist visa to an au pair who was clearly going to be working (Aly, 2018, see Berg, 2015 on au pairs in Australia and Cox, 2015 for comparison of au pair schemes internationally).

The UK is a country where au pairing is not regulated and which has in recent years, relied on the right of free movement of EEA nationals to meet demand for au pair labour. The lack of regulation means that there is no fixed official definition of an au pair, but broadly speaking, in the UK, au pairs are imagined to be young people, normally from another EU country, who will do $25-30 \mathrm{~h}$ of childcare and housework in exchange for room and board, 'pocket money' and being treated as 'a member of the family'. Until 2008 au pairing in the UK was regulated by the Home Office through the Au Pair Visa. The visa set out what an au pair could and could not do and the guidance it provided applied to all au pairs, even those from EU and EEA countries who did not need a visa (Búriková, 2016). In 2008 as part of a wider move to the Points Based Immigration Scheme (PBS) the au pair visa was ended and the government ceased to regulate au pairing (Cox 2012, Cox and Busch 2018). Currently the UK government provides a very limited amount of guidance about how to identify an au pair (see https://www.gov.uk/au-pairsemployment-law/au-pairs) but this information is vague and would allow people living and working in vastly different conditions to still be called au pairs. The only categorical statements this guidance provides are that au pairs are not entitled to the National Minimum Wage (NMW) or paid holidays, and that they are not normally classified as workers or employees. Au pairs are constructed as providing 'help' rather than labour for the families they live with. By defining au pairs as 'not workers' the government has removed any protections that may be available to them and created a sector where exploitation is rife and also largely unseen. There are no official records kept about the numbers of au pairs in Britain. Best, but very imprecise, estimates suggest there might have been 100,000 families hosting au pairs in 2013 (Cox and Busch, 2018).

\section{Gender and the boundaries of work and employment}

In order to understand how the labour of au pairs is presented as something other than work, it is worthwhile looking at how work and employment have been reorganised in recent years and how different groups of people are placed within labour markets, as well as considering the effects of the gendering of domestic tasks. Despite record numbers of people officially in employment in the UK (DWP, 2018), there has been increasing debate about who exactly is a 'worker'. Legal cases brought by Uber Drivers (ICAEW, 2017) and Deliveroo riders have sought to challenge the exclusion of 'platform workers' from the regular world of work (Barnett, 2018). The record employment figures it seems, are made up of ever larger numbers of 'self-employed' people, those on zero-hours contracts, 'working holiday makers' and others whose work arrangements exclude them from the protections given to 'employees'.

Along with changes to the organisation of work, there is a changing landscape of who does flexible and insecure work. In the UK, the Brexit process has revealed the extent to which the country is currently dependent on low-paid, highly flexible workers from other EU countries (Byrne, 2018; White, 2017). One sector that may be particularly affected by the loss of EU workers is care work; there are over 150,000 people from EU and EEA countries (excluding the UK) employed in the broad health and social care sector ( $5 \%$ of the total workforce) with $7 \%$ of the adult social care workforce $(90,000$ people) coming from those countries (Department of Health, 2017 p3; Sumpton, 2017). Au pairing could be even more affected by the end to free movement than adult social care, as since 2008 this sector has been almost entirely dependent on EU nationals who are able to work in Britain freely (Save au pairs, 2018).

This concentration of EU citizens (and other migrants) in precarious and flexible jobs is not a coincidence. There are various mechanisms which 'sort' people into different bits of the labour market and which fashion precarious workers. Bridget Anderson (2010) has argued that the migration system is one such, often overlooked, mechanism. Immigration controls produce categories of entrant with particular relations to employers and labour markets, they can institutionalise uncertainty and combine with less formalised migratory processes to help produce precarious workers. Workers with different levels of perceived skill, and of different nationalities are sorted into different bits of the labour market. Men and women can also be sorted into different forms of precarious work, 'bogus' self-employment in the construction industry for men versus hospitality or care work for women (see Búriková, 2016 for a discussion of how changes in 
migration status changed the position of Slovak au pairs in the labour market).

As well as workers not being equally seen as employees or workers, work is not all equally imagined to be 'real' work. Erin Hatton (2017) has argued that there are three intersecting sociological mechanisms that act to make work invisible: cultural, legal and spatial mechanisms. Work can be unseen because it is out of sight of the law, of cultural imaginings of work, behind closed doors or some combination of these. Domestic labour is affected by all three. Cultural assumptions naturalise this work when women do it, particularly when migrant women or Women of Colour do it for pay. Legal mechanisms do not recognise domestic work as bringing the same rights as other forms of work. Au pairs are not deemed to be workers in the UK and other live-in domestic workers are excluded from protections such as the right to National Minimum Wage (Moss, 2015). Last, domestic labour is invisible because it takes place in the home, a site which is itself constructed as somewhere where real work does not take place (Hatton, 2017).

$\mathrm{Au}$ pairs are described as 'helping' with housework and childcare rather than carrying out valuable and important labour. This conceptualisation of work as 'help' is highly gendered. It has its roots in the history of au pairing as a scheme which enabled middle class daughters to spend a period of time abroad with an equally middle class family learning some of the skills they would need to run their own homes after marriage and polishing up an additional language (Delap, 2011; Liarou, 2015). This imagining of the au pair is manifest in the idea that she does 'light housework', not 'the rough' which working class 'char' women were expected to do (Delap, 2011) and in the name 'au pair' meaning as 'as an equal'.

This construction of work as 'help' is available because of the centuries-long separation of housework from work outside the home, with only the latter being recognised as real and valuable work. The historian Leonore Davidoff (1995 p. 89) comments 'because it can never be really accepted that women's efforts in housework and household management should be measured in monetary terms, the worth of all women's work is affected.' She goes on to quote the Registrar General discussing changes in the way that women's work had been classified in recent censuses:

In 1881 and earlier, daughters and other female relatives of the Head of a Family, who were described as assisting in household duties, were classified as unoccupied. In 1891, however, it was considered that the nature of daily occupations of such persons being thus evident, they would be properly reckoned in Domestic Service ... In deciding on the rules of guidance of the clerks at the recent census (1901) however, we came to the conclusion that, on the whole, it would be better to revert to the method of 1881 (Census of Population General Report 1904, quoted in Davidoff, 1995 p. 89).

The British authorities were, it seems, unable to imagine housework as work, even when the 'daily occupations of such persons was evident'. When women carry out housework and childcare in the private home that labour is invisible-no matter how 'evident' it is. Au pairs can be imagined as 'helping' because it is the expectation that women will do these tasks, they are the 'natural' activities of female household members, not visible, valued work.

\section{The work that non-workers do}

In contemporary Britain, following the 2008 deregulation of au pairing, what au pairs actually do is a long way from a spot of flower arranging or dusting or whatever else 'light housework' might include. Analysis of 1000 advertisements for au pairs on Gumtree.com was carried out to gain an overview of the working hours, tasks and remuneration that characterised au pair posts (Cox and Busch, 2018). Our study found that the average working week being advertised was $38.7 \mathrm{~h}$ long (including babysitting) and that there was great variety in the number of hours an au pair was expected to work. A minority of ads was looking for an au pair for $25 \mathrm{~h}$ a week or fewer (the number of hours specified by the old $\mathrm{Au}$ Pair Visa) and 10 percent of all advertisers wanted an au pair to work $50 \mathrm{~h}$ a week or more, with the longest working week specified being $80 \mathrm{~h}$.

In return for this work the average pocket money offered was $£ 108$ per week (although only half of the ads revealed the amount on offer). Fourteen per cent offered below the recommended $£ 85$ pounds per week. For comparison, in 2013 (the year the ads were posted) someone recognised as a 'worker' and paid the adult minimum wage for $37.8 \mathrm{~h}$ per week would earn $£ 233.98$. From this, employers providing accommodation would be entitled to deduct $£ 33.74$ per week (under NMW rules no deductions are allowable for other benefits such as food) giving a total of $£ 200.24$ -nearly twice the average amount being offered to au pairs.

It was also striking that there was no correlation between the hours to be worked and the amount of pocket money offered. Three ads posted next to each other illustrate this variety in pay and conditions very well: the first offered $£ 100$ per week plus own bedroom and bathroom for $45 \mathrm{~h}$ work looking after four children, one of whom was under 3 and one of whom was under 1; the next offered $£ 100$ per week plus own bedroom for $50 \mathrm{~h}$ work looking after one child under 3; and the third offered $£ 110$ per week (no information given about bedroom or bathroom) for $25 \mathrm{~h}$ work looking after 3 children, none of whom was under 3 years old. The lowest pay offered was no pocket money, just room and board for $30 \mathrm{~h}$ work looking after a child under three years old and cooking and cleaning. The highest pay offered was c.£360 per week to care for two school age children after school during term time and full time during the holidays, as well as cooking and cleaning. Both of these were described by the advertisers as au pair posts. This variety suggests that hosts were offering a level of pay that they could afford rather than understanding that childcare and housework deserve a particular rate of pay (Cox and Busch, 2018).

The detail of these advertisements also illustrates that the work au pairs do has become more similar to that of nannies (Busch, 2015). The Au Pair Visa specifically stipulated that au pairs should not undertake sole charge care of babies and infants. Similarly, the British Au Pairs Agencies Association guidance (BAPAA, 2017) specifies that 'An Au Pair should not have any sole charge of children under the age of two. An au pair is not a qualified childcare provider'. However, with the deregulation of the sector it is increasingly common for au pairs to replace qualified nannies and to provide full time childcare and care for very young children. We found no real evidence of a qualitative difference in the tasks that au pairs 'helping' a family might be doing compared to those of a nanny or cleaner who was 'working'.

The trend to define domestic labour as something other than work and to exclude domestic workers from the protections given to other workers is not unique to au pairs, nor restricted to the UK. Around the world, even in the most enlightened countries such as Norway, au pairs and domestic workers are excluded from basic protections, such as the right to minimum wage or limited working hours (Cox, 2012, Cox, 2015, Løvdal 2015). In 2011 the International Labour Organisation (ILO) adopted a historic convention, No. 189 The Convention on Domestic Workers. This convention requires signatories to provide domestic workers with at least basic labour rights, such as the 
right to daily and weekly periods of rest, minimum wages, protection against violence, written contracts and the right to spend their leave where they chose (ILO, 2011). Despite the extremely limited nature of these protections, that should be available to all workers, to date the convention has been ratified by only 25 member states (ILO, 2018) the UK is not one of them.

\section{Conclusion}

Current debates about precarious forms of work, platform economies and the labour shortages likely to be caused by Brexit, have opened up a space where questions about the nature of work and who does the most precarious, low-paid and flexible work are being increasingly explored. Au pairs, have largely been excluded from these discussions, chiefly because of the invisibility of their work-both literally behind the closed doors of private houses, and more metaphorically within official records or statistics. We need to make sure that the gendering of our most basic understandings of what 'work' is are not left out of these conversations. There is an opportunity to recognise the real work of au pairs and other informal care workers and to give them the protections that all workers deserve.

Received: 21 August 2018 Accepted: 17 September 2018

Published online: 09 October 2018

\section{References}

Aly W (2018, August 30) Dutton's au pair drama shows hypocrisy of immigration policy. The Sydney Morning Herald. https://www.smh.com.au/politics/ federal/dutton-s-au-pair-drama-shows-hypocrisy-of-immigration-policy20180830-p500np.html. Accessed 13 Sep 2018

Anderson B (2010) Migration, immigration controls and fashioning of precarious workers. Work, Employ Soc 24(2):300-317

Anving T, Eldén S (2016) Precarious care labor: contradictory work regulations and practices for au pairs in Sweden. Nord J Work Life Stud 6(4):29-48

BAPAA (2017) What is an au pair? BAPAA.org.uk. http://bapaa.org.uk/hostfamilies/what-is-an-au-pair/. Accessed 20 Aug 2018

Barnett V (2018) Recent UK Uber and Deliveroo cases, Keystone Law. https:// keystonelaw.co.uk/keynotes/recent-uk-uber-and-deliveroo-cases. Accessed 16 Aug 2018

Berg L (2015) Hiding in plain sight-Au pairs in Australia. In: Cox R (ed) Au pairs' lives in global context: sisters or servants? Palgrave Macmillan, Basingstoke, $\mathrm{p}$ $187-202$

Búriková ZS (2016) Eu enlargement and au pairing in the United Kingdom. Nord J Migr Res 6(4):207-214

Busch N (2015) When work doesn't pay: outcomes of a deregulated childcare market and au pair policy vacuum in the UK. In: Cox R (ed) Au pairs' lives in global context: sisters or servants? Palgrave Macmillan, Basingstoke, p 53-69

Byrne R (2018) The migrant labour shortage is already here and agri-tech can't fill the gap. LSE Blogs. http://blogs.lse.ac.uk/brexit/2018/01/05/the-migrantlabour-shortage-is-already-here-and-agri-tech-cant-yet-fill-the-gap. Accessed 16 Aug 2018

Calleman C (2010) Cultural exchange or cheap domestic labour? Constructions of 'au pair' in four Nordic countries. In: Isaksen L W (Ed.) Global Care Work: Gender and Migration in Nordic societies. Nordic Academic Press, Lund, p 69-96

Chuang JA (2013) The U.S. au pair program: labour exploitation and the myth of cultural exchange. Harv J Law Gend 36:270-343

Cox R (2012) Invisible au pairs: Gendered work and migration regimes. In: Sollund $\mathrm{R}$ (ed) Transnational migration, gender and rights, advances in ecopolitics Vol. 10. Emerald Group Publishing, Bingley, p. 33-52

Cox R (2015) Conclusion: When is a worker not a worker? Tackling the contradictions of au pairing. In: Cox R (ed) Au pairs' lives in global context: sisters or servants? Palgrave Macmillan, Basingstoke, p. 235-249

Cox R, Busch N (2018) As an equal? Au pairing in the twenty-first century. Zed Books, London

Davidoff L (1995) Worlds between: historical perspectives on gender and class. Polity Press, Cambridge
Delap L (2011) Knowing their place: domestic service in twentieth-century Britain. Oxford University Press, Oxford

Department of Health (2017) Evidence on EEA nationals working within the health and care system, focusing on England Department of Health https://assets.publishing.service.gov.uk/government/uploads/system/uploads/ attachment_data/file/693468/Department_of_Health.pdf. Accessed 16 Aug 2018

Department for Work and Pensions (DWP) (2018) Employment rate remains at record high. Gov.UK. https://www.gov.uk/government/news/employmentrate-remains-at-record-high. Accessed 16 Aug 2018

Hatton E (2017) Mechanisms of invisibility: rethinking the concept of invisible work. Work, Employ Soc 32(2):336-351

ICAEW (2017) Case law: Court of appeals confirms that Uber drivers are to be treated as workers. ICAEW. https://www.icaew.com/library/subject-gateways/ law/legal-alert/2017-12/case-law-court-of-appeal-confirms-uber-drivers-areto-be-treated-as-workers. Accessed 16 Aug 2018

ILO (2011) Convention 189 and Recommendation 201 0n Decent Work for Domestic Workers. International Labour Organisation. https://www.ilo.org/ travail/whatwedo/publications/WCMS_168266/lang--en/index.htm. Accessed 16 Aug 2018

ILO (2018) Convention No. 189 on domestic workers ratified by Brazil. International Labour Organisation. http://www.ilo.org/global/about-the-ilo/ newsroom/news/WCMS_616549/lang--en/index.htm. Accessed 16 Aug 2018

Liarou E (2015) 'Pink slave' or 'modern young woman'? A history of the au pair in Britain'. In: Cox R (ed) Au pairs' lives in global context: sisters or servants? Palgrave Macmillan, Basingstoke, p. 19-35

Løvdal L (2015) Au pairs in Norway: experiences from an outreach project. In: Cox $\mathrm{R}$ (ed) Au pairs' lives in global context: sisters or servants? Palgrave Macmillan, Basingstoke, p. 136-154

Moss J (2015) Migrant domestic workers, the National Minimum Wage and the 'family worker' exemption. In: Cox R (ed) Au pairs' lives in global context: sisters or servants? Palgrave Macmillan, Basingstoke, p. 70-86

Save au pairs (2018) \#SAVEAUPAIRS Save au pairs. https://saveaupairs.uk/. Accessed 16 Aug 2018

Sumpton M (2017) Labour immigration after Brexit: Trade-offs and questions about policy design. The Migration Observatory at the University of Oxford. http://migrationobservatory.ox.ac.uk/wp-content/uploads/2017/01/ReportLabour_Immigration_Policy_Brexit.pdf. Accessed 20 Aug 2018

White A (2017) Time for Britain to face up to its post-Brexit skills shortage. The Conversation. http://theconversation.com/time-for-britain-to-face-up-to-itspost-brexit-skills-shortage-87295. Accessed 16 Aug 2018

\section{Acknowledgements}

This research was made possible by ESRC Grant ES/J007528/1. My thanks go to Nicky Busch for her work on the project and many conversations about the nature of au pairs' (non) work.

\section{Additional information}

Competing interests: The author declares no competing interests.

Reprints and permission information is available online at http://www.nature.com/ reprints

Publisher's note: Springer Nature remains neutral with regard to jurisdictional claims in published maps and institutional affiliations.

pen Access This article is licensed under a Creative Commons Attribution 4.0 International License, which permits use, sharing, adaptation, distribution and reproduction in any medium or format, as long as you give appropriate credit to the original author(s) and the source, provide a link to the Creative Commons license, and indicate if changes were made. The images or other third party material in this article are included in the article's Creative Commons license, unless indicated otherwise in a credit line to the material. If material is not included in the article's Creative Commons license and your intended use is not permitted by statutory regulation or exceeds the permitted use, you will need to obtain permission directly from the copyright holder. To view a copy of this license, visit http://creativecommons.org/ licenses/by/4.0/.

(C) The Author(s) 2018 